\title{
Supplementation of Yearling Steers Grazing Fertilized and Unfertilized Northern Plains Rangeland
}

\author{
J.F. KARN AND R.J. LORENZ
}

\section{Abstract}

Supplementation studies were conducted with yearling steers on a silty range site in central North Dakota, where yearly precipitation averaged 380 to $410 \mathrm{~mm}$. The studies were conducted for 3 summers on both fertilized ( $45 \mathrm{~kg} \mathrm{~N} / \mathrm{ha}$ ) and unfertilized native pastures. Animal performance was compared to seasonal changes in the chemical composition of pasture samples collected with esophageal-fistulated steers. Chemical composition differences between diet samples from the fertilized and unfertilized pastures were inconsistent, but generally protein was higher and acid detergent fiber lower on the fertilized pasture. Supplementation with barley in the early summer resulted in little benefit, but supplementation with barley in the late summer, especially when pasture digestibility (in vitro) dropped to 50 to $52 \%$, was beneficial on both the fertilized and unfertilized pastures. However, the response was not consistent between years. Barley supplementation appeared to be economically viable, but the feasibility of this practice will vary from year to year, depending on the price of barley relative to the price of steers. The results of protein supplementation were more erratic, possibly because of differences in precipitation patterns and hence plant growth between years.

Native rangelands in the Northern Great Plains support good summer weight gains on yearling steers. Therefore, little consideration has been given to use of supplements which might produce still greater and more efficient gains. Rogler and Lorenz (1965) have shown that beef cattle carrying capacity of the Northern Great Plains mixed grass prairie can be approximately doubled with appropriate nitrogen fertilization. However, fertilization was shown to favor the growth of cool-season midgrasses, particularly western wheatgrass (Agropyron smithii), with an associated reduction in the stand of blue grama (Bouteloua gracilis), a warm-season shortgrass (Lorenz and Rogler 1972). This shift in species composition alters the seasonal growth pattern and may affect the nutritional value of the grazing animal's diet.

There is limited information available on the chemical composition of native forages in the Northern Great Plains, especially with respect to changes during the grazing season. Information available on the value of supplementing yearling steers grazing native forage is also limited. However, Ralcigh (1970) reported positive results from a supplementation scheme developed for use in eastern Oregon. Both crude protein (CP) and energy were supplemented as required to complement the diet of yearling steers grazing crested wheatgrass (Agropyron desertorum). A beneficial effect from energy supplementation of stee rs grazing spring native range in eastern Colorado has been reported by Denham (1977). These results suggested that $\mathrm{CP}$ and/or energy supplementation might also be beneficial to grazing steers in the Northern Plains. Thus the objectives of this study were: (1) to determine the chemi-

Authors are research animal scientist and research agronomist, USDA-ARS, Northern Great Plains Research Laboratory, P.O. Box 459, Mandan, N.D. 58554.

Authors wish to acknowledge Mr. Charles Graham for his assistance with statistical procedures and Mr. Richard Huppler and Mrs. Margo Dockter for their techncial assistance.

Manuscript received May 11, 1980. cal composition of esophageal fistula diet collections taken from fertilized and unfertilized native range throughout the grazing season, and (2) to study the effect of CP and energy supplementation on the performance of yearling steers grazing these rangelands.

\section{Materials and Methods}

Summer supplementation studies were undertaken in 1977, 1978, and 1979 on a Northern Great Plains silty range site in the 380-410 mm rainfall area of central North Dakota. Predominate forage species were western wheatgrass (Agropyron smithii), prairie junegrass (Koeleria cristata), blue gra ma (Bouteloua gracilis), needleandthread (Stipa comata), green needlegrass (Stipa viridula), and upland scdges (Carex spp.). Big bluestem (Andropogon gerardii) was present in low areas and along intermittent waterways. The experimental site had been previously separated into 2 pastures. The smaller of these ( 14.2 hectares) had been fertilized annually for 20 years with $45 \mathrm{~kg}$ nitrogen per hectare $(45-\mathrm{N})$. This practice was continued during these studies. The other pasture contained 28.4 hectares and had not been fertilized $(0-N)$. The same number of steers were grazed on each pasture based on results of work by Rogler and Lorenz (1965), which demonstrated that a hectare of fertilized rangeland would support twice as many steers as a hectare of unfertilized rangeland.

Five esophageal-fistulated steers were used to collect weekly diet samples from each pasture in 1977 and 1978 . The 1977 study was conducted from mid-May until mid-September and the 1978 study from mid-May until mid-October. In 1979 diet samples were collected every second week from mid-May to mid-October using 6 esophageal-fistulated steers. Diet samples were collected from both pastures the same day by using the same steers. To avoid a possible pasture bias, samples were collected one week from the 45- $\mathrm{N}$ pasture first and the next week from the $0-\mathrm{N}$ pasture first. Obioha et al. (1970), reported slight but significant differences in nitrogen level between morning and evening forage samples collected via esophageal fistula. The difference was attributed to differences in grazing selectivity due to hunger. In our study samples were collected from pastures in the morning, with samples collected from the second pasture immediately following the first. Esophageal-fistulated steers were maintained on an adjacent $\mathbf{0 - N}$ native pasture and were not supplemented. They were kept off feed the night before sampling to facilitate diet collections.

Diet samples collected by individual steers were dried to a constant weight at $50^{\circ} \mathrm{C}$ in shallow pans in a forced draft oven then ground throught a 1-mm screen in a Wiley mill. Chemical analysis included Kjeldahl nitrogen, in vitro digestible organic matter (Tilley and Terry 1963, Moore and Mott 1974), neutral detergent fiber (Van Soest and Wine 1967), acid detergent fiber (ADF) and lignin (Van Soest and Wine 1968). In 1978 and 1979 diet samples from individual steers were processed the same as in 1977. Kjeldahl nitrogen was measured on each sample, but the other chemical analyses were performed on a composite sample for each pasture 

Table 1. Chemical composition of forage samples collected via esophagel fistulated steers during the summer grazing season from native range receiving
45-N and 0-N (1977).,

\begin{tabular}{|c|c|c|c|c|c|c|c|c|c|c|c|c|c|c|c|}
\hline \multirow[t]{2}{*}{ Month } & \multicolumn{2}{|c|}{$\begin{array}{c}\text { IVDOM } \\
\% \\
\text { Pasture } \\
\end{array}$} & \multirow[b]{2}{*}{ Mean } & \multicolumn{2}{|c|}{$\begin{array}{c}\text { CP } \\
\text { \% of D.M. } \\
\text { Pasture }\end{array}$} & \multirow[b]{2}{*}{ Mean } & \multicolumn{2}{|c|}{$\begin{array}{c}\text { NDF } \\
\text { \% of D.M. } \\
\text { Pasture } \\
\end{array}$} & \multirow[b]{2}{*}{ Mean } & \multicolumn{2}{|c|}{$\begin{array}{c}\text { ADF } \\
\% \text { of D.M. } \\
\text { Pasture } \\
\end{array}$} & \multirow[b]{2}{*}{ Mcan } & \multicolumn{2}{|c|}{$\begin{array}{c}\text { Lignin } \\
\% \text { of D.M. } \\
\text { Pasture }\end{array}$} & \multirow[b]{2}{*}{ Mean } \\
\hline & $45-\mathrm{N}$ & $0-\mathrm{N}$ & & $45-N$ & $0-\mathrm{N}$ & & $45-N$ & $0-N$ & & $45-N$ & $0-\mathrm{N}$ & & $45-N$ & $0-\mathrm{N}$ & \\
\hline May $^{3}$ & 66.2 & 62.4 & 64.3 & 19.1 & 12.8 & 16.0 & 56.6 & 66.6 & 61.6 & 33.5 & 40.8 & 37.2 & 7.6 & 6.5 & 7.0 \\
\hline June & 59.7 & 57.4 & 58.6 & 13.4 & 10.5 & 12.0 & 69.4 & 70.6 & 70.0 & 39.1 & 44.3 & 41.7 & 6.4 & 8.2 & 7.3 \\
\hline July & 56.6 & 53.6 & 55.1 & 12.7 & 8.8 & 10.8 & 70.6 & 70.6 & 70.6 & 41.5 & 44.6 & 43.0 & 7.2 & 7.7 & 7.4 \\
\hline August & 58.2 & 52.5 & 55.4 & 12.2 & 7.9 & 10.0 & 67.3 & 66.4 & 66.8 & 42.2 & 46.6 & 44.4 & 7.4 & 9.1 & 8.2 \\
\hline Scptember & 60.3 & 55.9 & 58.1 & 16.2 & 12.6 & 14.4 & 64.5 & 66.1 & 65.3 & 39.1 & 46.8 & 43.0 & 6.8 & 9.6 & 8.2 \\
\hline mean & $60.2^{\mathrm{a}}$ & $56.4^{b}$ & 58.3 & $14.7^{\mathrm{a}}$ & $10.5^{\mathrm{b}}$ & 12.6 & $65.7^{a}$ & $68.1^{b}$ & 66.9 & $39.1^{\mathrm{a}}$ & $44.6^{b}$ & 41.9 & $7.1^{2}$ & $8.2^{\mathrm{b}}$ & 7.6 \\
\hline
\end{tabular}

I Pasture means with the same heading and different superscripts differ significantly $(P<.05)$.

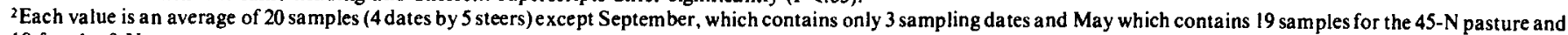
18 for the $0-\mathrm{N}$ pasture.

'Contains June 2 sampling date.

for each sampling date. Data were a nalyzed by collection period by using either an arithmetic mean of data from individual diet samples or data from the chemical analysis of a composite sample.

\section{Study}

Twenty yearling Hereford steers weighing approximately $265 \mathrm{~kg}$ were randomly assigned to either the $45-\mathrm{N}$ or $0-\mathrm{N}$ pasture. Five steers on each pasture were then randomly assigned to one of the following treatments: (1) no supplement, or (2) $.9 \mathrm{~kg}$ dry rolled barley containing $2.7 \mathrm{Mcal} \mathrm{DE}$ and $119 \mathrm{gm} \mathrm{CP}$. Steers were corralled each morning before 1000 hours CDT and those that received supplement were individually fed. Refused supplement was weighed and subtracted from the a mount offered. The experiment was started June 1 and terminated July 22 because of a severe drought and consequent lack of forage, which forced removal of the steers from the pasture. All steers had continual access to a 50-50 mixture of salt and dicalcium phosphate.

Initial and final steer weights represented an average of 2 weighings each, 24 hours a part. Intermediate weights were taken approximately every 2 weeks. All weights were taken following an overnight stand without feed or water.

\section{Study}

This study was initiated June 2 and continued a full 152-day grazing season, but was divided into two periods. Feeding and weighing procedures were the same as in 1977 . In the early summer (ES) period 30 yearling Hereford steers weighing $267 \mathrm{~kg}$ were randomly assigned to either the $45-\mathrm{N}$ or $0-\mathrm{N}$ pasture, then 5 steers on each pasture were randomly assigned to each of the following treatments: (1) no supplement, (2) $.68 \mathrm{~kg}$ dry rolled barley $(2.0$ Mcal DE and $87 \mathrm{gm} \mathrm{CP}$ ) or (3) $.68 \mathrm{~kg}$ brewers grains (1.8 Mcal DE and $179 \mathrm{gm} \mathrm{CP}$ ). Steers offered brewers grains consumed this supplement very poorly, thus their data were not included in the ES results. The ES period was terminated after 45 days and the late summer (LS) period continued the last 107 days of the grazing season. Treatments 1 and 2 were continued, but treatment 3 was changed to $.45 \mathrm{~kg}$ soybean meal and $.23 \mathrm{~kg}$ rolled barley $(2.1 \mathrm{Mcal}$ $\mathrm{DE}$ and $247 \mathrm{gm} \mathrm{CP}$ ). Steers averaged $322 \mathrm{~kg}$ when the $\mathrm{LS}$ period began.

\section{Study}

Thirty yearling Hereford steers, weighing $308 \mathrm{~kg}$, were implanted with $30 \mathrm{mg}$ diethylstilbestrol and individually supplemented as in 1977 and 1978. Supplementation treatments were:(1) no supplement, (2) .68 kg dry rolled barley $(2.0 \mathrm{Mcal}$ DE and $87 \mathrm{gm}$ CP), and (3) .68 kg brewers grains containing $1.8 \mathrm{Mcal} \mathrm{DE}$ and 179 gm CP. The study was not initiated until July 19 because the greatest benefit to supplementation in 1978 appeared to be in the LS and fall period. Steers were removed from the $45-\mathrm{N}$ pasture September 21 and from the 0-N pasture October 19.

Poor acceptance of the feeding procedure by steers had been a problem in 1977 and 1978. Thus, during the early part of the summer of 1979 , steers were trained to use the individual feeding equipment to facilitate supplementation when the study was initiated.

Weight gains for each pasture, each period, and each year were analyzed separately, then the two years of ES data and the two years of LS data were analyzed as randomized complete blocks. Treatment differences were determined by Duncan's multiple range test and were considered statistically significant at the $5 \%$ level of probability.

\section{Results}

\section{Study}

\section{Forage Chemical Composition}

Steer differences in diet selection on the $45-\mathrm{N}$ pasture were reflected by standard errors in the $\mathrm{CP}$ content of weekly diet

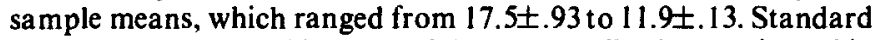
errors were comparable on the $0-\mathrm{N}$ pasture. Crude protein and in vitro digestible organic matter (IVDOM) were higher $(P<.05)$ and neut ral detergent fibcr (NDF), ADF, and lignin lower $(R<.05)$ for the 45-N compared to the $0-\mathrm{N}$ pasture (Table 1). Although NDF was lower $(P<.05)$ on the $45-\mathrm{N}$ pasture, monthly averages shown in Table 1 indicate that differences were primarily in the May samples. There was a difference $(P<.05)$ in CP and IVDOM values between periods, with a general decline through August followed by an increase in September. Neutral detergent fiber and ADF values were also different $(P<.05)$ between periods, showing a gradual seasonal increase followed by a decrease in NDF in August and ADF in September. Lignin was not different $(P>.05)$ between sampling periods. The greatest decline in $\mathrm{CP}$ and IVDOM occurred between May and June when the paucity of forage precluded grazing. The increase in CP and IVDOM in late summer was a reflection of unusually heavy rainfall (Table 2), resulting in new forage growth which was selected by the fistulated steers. The September decline in NDF, ADF, and lignin in 45-N pasture diet samples was also indicative of higher forage quality. However, NDF, ADF, and lignin in diet samples from the $0-\mathrm{N}$ pasture changed little in September.

\section{Animal Performance}

Results of the supplementation study (Table 3) show that steers

Table 2. Growing season precipitation (mm).

\begin{tabular}{lrrrc}
\hline \hline & & & & Mean \\
Month & 1977 & 1978 & 1979 & $1915-1979$ \\
\hline May & 37 & 107 & 19 & 55 \\
June & 57 & 72 & 34 & 86 \\
July & 42 & 44 & 167 & 60 \\
August & 47 & 13 & 41 & 41 \\
September & 244 & 53 & 21 & 38 \\
October & 32 & 9 & 4 & 22 \\
\hline
\end{tabular}


Table 3. Effect of supplementation on daily gains (kg) of yearling steers during early and late summer periods. ${ }^{1}$

\begin{tabular}{|c|c|c|c|c|c|c|c|c|c|c|}
\hline \multirow[b]{3}{*}{ Supplement } & \multicolumn{4}{|c|}{ Early Summer } & \multirow{3}{*}{$\begin{array}{c}\text { Mean } \\
\text { ES }\end{array}$} & \multicolumn{4}{|c|}{ Late Summer } & \multirow{3}{*}{$\begin{array}{c}\text { Mean } \\
\text { LS }\end{array}$} \\
\hline & \multicolumn{2}{|c|}{1977} & \multicolumn{2}{|c|}{1978} & & \multicolumn{2}{|c|}{1978} & \multicolumn{2}{|c|}{1979} & \\
\hline & $45-\mathrm{N}$ & $0-N$ & $45-\mathrm{N}$ & $0-\mathrm{N}$ & & $45-\mathrm{N}$ & $0-\mathrm{N}$ & $45-\mathrm{N}$ & $0-\mathrm{N}$ & \\
\hline $\begin{array}{l}\text { No Supp. } \\
\text { Barley } \\
\text { CP Supp. }\end{array}$ & $\begin{array}{c}.89^{92} \\
1.08^{\mathrm{a}} \\
-\end{array}$ & $\begin{array}{l}1.11^{\mathrm{a}} \\
1.32^{\mathrm{b}} \\
-\end{array}$ & $\begin{array}{l}1.22^{a} \\
1.24^{a} \\
-\end{array}$ & $\begin{array}{l}1.14^{\mathrm{a}} \\
1.19^{\mathrm{a}} \\
-\end{array}$ & $\begin{array}{l}1.09^{\mathrm{a}} \\
1.20^{\mathrm{a}} \\
-\end{array}$ & $\begin{array}{l}.20^{\mathrm{a}} \\
.31^{\mathrm{b}} \\
.36^{\mathrm{b}}\end{array}$ & $\begin{array}{l}.47^{\mathrm{a}} \\
.54^{\prime \prime} \\
.52^{\mathrm{a}}\end{array}$ & $\begin{array}{l}.84^{\mathrm{a}} \\
.94^{\mathrm{a}} \\
.89^{\mathrm{a}}\end{array}$ & $\begin{array}{l}.66^{\mathrm{a}} \\
.82^{\mathrm{b}} \\
.78^{\mathrm{b}}\end{array}$ & $\begin{array}{l}.54^{\mathrm{a}} \\
.65^{\mathrm{b}} \\
.64^{\mathrm{b}}\end{array}$ \\
\hline
\end{tabular}

'Days on supplement; $1977=51,1978 \mathrm{ES}=45,1978 \mathrm{LS}=107,197945-\mathrm{N}=63,19790-\mathrm{N}=91$.

2 Means in a column with the same superscript are not different $(P>.05)$.

31977, $2.67 \mathrm{Mcal} \mathrm{DE}$ and $104 \mathrm{gm} \mathrm{CP} ; 1978$ and 1979, $1.95 \mathrm{Mcal} \mathrm{DE}$ and $87 \mathrm{gm} \mathrm{CP}$, values based on actual consumption.

$41978 \mathrm{LS}$ (soy-barley), $2.06 \mathrm{Mcal} \mathrm{DE}$ and $242 \mathrm{gm} \mathrm{CP} ; 1979$ (brewers grains), $1.69 \mathrm{Mcal} \mathrm{DE}$ and $168 \mathrm{gm} \mathrm{CP}$, values based on actual consumption.

fed barley on the $45-\mathrm{N}$ pasture tended to gain better $(1.08 \mathrm{~kg} / \mathrm{da})$ than unsupplemented steers $(.89 \mathrm{~kg} / \mathrm{da})$, but the difference was not statistically significant. Steers supplemented with barley on the $0-\mathrm{N}$ pasture did, however, gain more $(P<.05)$ than controls $(1.32 \mathrm{vs}$ $1.11 \mathrm{~kg} / \mathrm{da})$. The response of steers to supplemental energy in this experiment may have been due to a shortage of forage, rather than to a decline in forage quality. The experimental design called for both energy and CP supplementation during the late summer and and fall, but drought induced lack of forage caused the study to be terminated following the early summer period.

\section{Study}

\section{Forage Chemical Composition}

Chemical composition of diet samples from the 45-N and $0-\mathrm{N}$ pastures are shown in Table 4. Crude protein and NDF were higher $(P<.05)$ for the $45-\mathrm{N}$ pasture while lignin was higher $(P<.05)$ for the $0-\mathrm{N}$ pasture. The presence of mature western wheatgrass beginning in late June probably accounted for the high NDF for the 45-N pasture. Acid detergent fiber and IVDOM tended to be higher for the $0-\mathrm{N}$ pasture, but differences were not significant.

Crude protein and IVDOM decreased $(P<.05)$ throughout the season while NDF, ADF, and lignin increased $(P<.05)$ as the season progressed. The greatest change in NDF and IVDOM, however, had occurred by June and July, respectively. Crude protein and ADF changed more gradually throughout the season. Although lignin differed $(P<.05)$ between sampling times, there was not a consistent seasonal trend for the $45-\mathrm{N}$ pasture.

\section{Animal Performance}

Steers supplemented with barley during the ES period gained little better $(P>.05)$ than unsupplemented steers on either pasture (Table 3). However, in the LS period, steers that received either barley or a $\mathrm{CP}$ supplement on the $45-\mathrm{N}$ pasture had greater $(P<.05)$ weight gains than unsupplemented steers (Table 3 ). The efficiency of supplement utilization was calculated by dividing the amount of supplement consumed by the difference in gain between supplemented and unsupplemented steers. Efficiencies were 5.9 and 4.4 $\mathrm{kg}$ feed/ $\mathrm{kg}$ gain, respectively, for the barley and $\mathrm{CP}$ supplemented steers. Steers fed either barley or the CP supplement on the $0-\mathrm{N}$ pasture tended to gain more than unsupplemented steers, but differences were not significant.

Average cumulative weight gains of steers on the $45-\mathrm{N}$ and $0-\mathrm{N}$ pastures for both the ES and LS periods were combined by weighing period and plotted with combined diet $\mathrm{CP}$ and IVDOM values (Fig. 1). Diet CP dropped below the NRC requirement (National Research Council 1976) for $350 \mathrm{~kg}$ steers to gain $.9 \mathrm{~kg}$ per day by August 3. There was little response to supplemental $\mathrm{CP}$ at this time, but animal gains were only about $.3 \mathrm{~kg} /$ day regardless of treatment. Protein supplementation appeared beneficial beginning

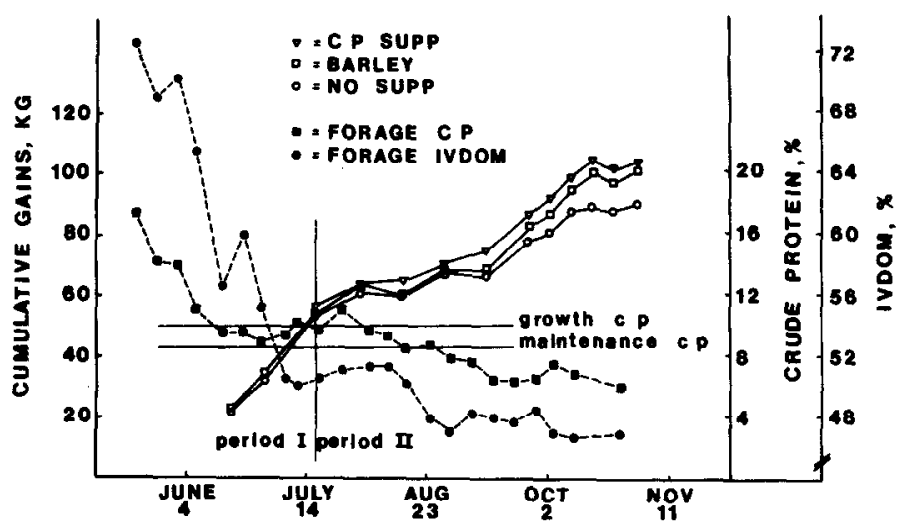

Fig. 1. Cumulative weight gains, forage CP and IVDOM, 1978.

Table 4. Chemical composition of forage samples collected vix esophageal fistulated steers during the summer grazing season from native range receiving 45-N and 0-N (1978).1

\begin{tabular}{|c|c|c|c|c|c|c|c|c|c|c|c|c|c|c|c|}
\hline \multirow[b]{2}{*}{ Month } & \multicolumn{2}{|c|}{$\begin{array}{c}\text { IVDOM }^{2} \\
\% \\
\text { Pasture }\end{array}$} & \multirow[b]{2}{*}{ Mean } & \multicolumn{2}{|c|}{$\begin{array}{c}\text { CP }^{3} \\
\text { \% of D.M. } \\
\text { Pasture }\end{array}$} & \multirow[b]{2}{*}{ Mean } & \multicolumn{2}{|c|}{$\begin{array}{c}\text { NDF}^{2} \\
\text { \% of D.M. } \\
\text { Pasture }\end{array}$} & \multirow[b]{2}{*}{ Mean } & \multicolumn{2}{|c|}{$\begin{array}{c}\text { ADF }^{2} \\
\% \text { of D.M. } \\
\text { Pasture }\end{array}$} & \multirow[b]{2}{*}{ Mean } & \multicolumn{2}{|c|}{$\begin{array}{c}\text { Lignin }{ }^{2} \\
\% \text { of D.M. } \\
\text { Pasture }\end{array}$} & \multirow[b]{2}{*}{ Mean } \\
\hline & $45-N$ & $0-\mathrm{N}$ & & $45-N$ & $0-\mathrm{N}$ & & $45-\mathrm{N}$ & $0-\mathrm{N}$ & & $45-\mathrm{N}$ & $0-\mathrm{N}$ & & $\overline{45-N}$ & $0-\mathrm{N}$ & \\
\hline $\mathrm{May}^{4}$ & 71.1 & 70.5 & 70.8 & 16.4 & 14.1 & 15.2 & 50.4 & 59.1 & 54.8 & 33.7 & 36.9 & 35.3 & 8.0 & 6.7 & 7.4 \\
\hline June & 60.6 & 58.0 & 59.3 & 10.9 & 8.9 & 9.9 & 70.8 & 66.5 & 68.6 & 42.0 & 41.5 & 41.8 & 7.0 & 6.7 & 6.8 \\
\hline July & 47.3 & 53.8 & 50.6 & 10.2 & 10.0 & 10.1 & 70.9 & 67.2 & 69.0 & 44.2 & 45.7 & 45.0 & 8.2 & 9.2 & 8.7 \\
\hline August & 50.0 & 50.3 & 50.2 & 9.4 & 8.7 & 9.0 & 70.4 & 66.0 & 68.2 & 45.9 & 47.1 & 46.5 & 8.4 & 10.0 & 9.2 \\
\hline September & 48.1 & 47.3 & 47.7 & 6.9 & 7.2 & 7.0 & 73.7 & 64.7 & 69.2 & 48.8 & 48.6 & 48.7 & 8.0 & 10.8 & 9.4 \\
\hline October & 45.7 & 48.7 & 47.2 & 7.8 & 5.5 & 6.6 & 73.1 & 70.7 & 71.9 & 50.3 & 51.6 & 51.0 & 9.2 & 9.3 & 9.2 \\
\hline mean & $53.8^{n}$ & $54.8^{\mathrm{a}}$ & 54.3 & $10.3^{\mathrm{A}}$ & $9.1^{b}$ & 9.7 & $68.2^{\mathrm{a}}$ & $65.7^{b}$ & 67.0 & $44.2^{\mathrm{a}}$ & $45.2^{a}$ & 44.7 & $8.1^{\mathrm{a}}$ & $8.8^{b}$ & 8.4 \\
\hline
\end{tabular}

'Pasture means with the same heading and different superscripts are different $(\mathcal{A}<.05)$.

2Values represent an average of 4 composite samples for all months except May which had only 3.

3Values represent an average of 20 individual sa mples ( 4 dates and 5 steers) except for May which contained only 3 sampling dates and July when the $45-\mathrm{N}$ past ure contained only 19 samples.

4For convenience, a June 1 date was included in the May average, an August 31 date was included in the September average, and a September 28 date was included in the October average. 
Table 5. Chemical composition of forage samples collected via esophageal fistulated steers during the summer grazing season from native range receiving 45-N and 0-N (1979). 1

\begin{tabular}{|c|c|c|c|c|c|c|c|c|c|c|c|c|c|c|c|}
\hline \multirow[b]{2}{*}{ Month } & \multicolumn{2}{|c|}{$\begin{array}{c}\text { IVDOM } \\
\% \\
\text { Pasture } \\
\end{array}$} & \multirow[b]{2}{*}{ Mean } & \multicolumn{2}{|c|}{$\begin{array}{c}\text { CP3 } \\
\text { \% of D.M. } \\
\text { Pasture }\end{array}$} & \multirow[b]{2}{*}{ Mean } & \multicolumn{2}{|c|}{$\begin{array}{c}\text { NDF }^{2} \\
\% \text { of D.M. } \\
\text { Pasture }\end{array}$} & \multirow[b]{2}{*}{ Mean } & \multicolumn{2}{|c|}{$\begin{array}{c}\text { ADF }^{2} \\
\% \text { of D.M. } \\
\text { Pasture }\end{array}$} & \multirow[b]{2}{*}{ Mean } & \multicolumn{2}{|c|}{$\begin{array}{c}\text { Lignin }{ }^{2} \\
\% \text { of D.M. } \\
\text { Pasture }\end{array}$} & \multirow[b]{2}{*}{ Mean } \\
\hline & $45-N$ & $0-N$ & & $45-N$ & $0-N$ & & $45-N$ & $0-N$ & & $45-N$ & $0-\mathrm{N}$ & & $45-N$ & $0-N$ & \\
\hline May & 62.1 & 60.1 & 61.1 & 17.0 & 10.5 & 13.8 & 53.4 & 66.7 & 60.0 & 34.4 & 43.5 & 39.0 & 5.9 & 6.1 & $\overline{6.0}$ \\
\hline June & 64.9 & 59.6 & 62.2 & 17.9 & 12.0 & 15.0 & 58.0 & 69.5 & 63.8 & 35.0 & 44.9 & 40.0 & 7.1 & 8.0 & 7.6 \\
\hline July & 60.4 & 51.0 & 55.7 & 14.3 & 12.4 & 13.4 & 70.8 & 67.3 & 69.0 & 40.3 & 46.9 & 43.6 & 6.8 & 10.8 & 8.8 \\
\hline August & 54.3 & 52.7 & 53.5 & 11.5 & 8.7 & 10.1 & 69.7 & 68.6 & 69.2 & 42.6 & 45.7 & 44.2 & 7.5 & 7.9 & 7.7 \\
\hline September & 51.4 & 52.5 & 52.0 & 9.9 & 6.9 & 8.4 & 71.7 & 69.8 & 70.8 & 45.5 & 49.8 & 47.6 & 7.7 & 8.4 & 8.0 \\
\hline October & 50.2 & 50.6 & 50.4 & 8.8 & 6.1 & 7.4 & 71.4 & 71.5 & 71.4 & 47.3 & 50.6 & 49.0 & 7.8 & 9.2 & 8.5 \\
\hline Mean & $57.2^{\mathrm{a}}$ & $54.4^{b}$ & 55.8 & $13.2^{a}$ & $9.4^{b}$ & 11.3 & $65.8^{a}$ & $68.9^{n}$ & 67.4 & $40.8^{a}$ & $46.9^{b}$ & 43.8 & $7.1^{a}$ & $8.4^{b}$ & 7.8 \\
\hline
\end{tabular}

iPasture means with the same heading and different superscripts are different $(P<.05)$.

2Values represent an average of 2 composite samples for all months except May, which had 1 , and July, which had 3.

'Values for June, September, and October represent an average of 12 individual samples (2 dates and 6 steers). May, July, and August values represent an average of 6, 18 , and 11 samples, respectively.

about August 23 when CP in the forage dropped below the NRC maintenance requirement $(8.5 \%)$. The response to both $\mathrm{CP}$ and barley supplementation was increasingly evident through midOctober.

Forage IVDOM declined quickly from almost $73 \%$ in mid-May to $50 \%$ by mid-July. During mid-summer, animal performance appeared to be related to forage IVDOM, but in the fall animal performance increased while IVDOM continued to decline. Barley supplementation was effective in the fall when forage IVDOM was low.

\section{Study}

\section{Forage Chemical Composition}

Crude protein and IVDOM were higher $(P<.05)$ and ADF and lignin lower $(P<.05)$ for the $45-\mathrm{N}$ pasture compared to the $0-\mathrm{N}$ pasture (Table 5). However, there was not a significant difference in NDF between the pastures. Crude protein and IVDOM decreased $(P<.05)$ and ADF increased $(P<.05)$ as the season progressed. Lignin and NDF tended to increase as the season advanced, but seasonal differences were not significant.

\section{Animal Performance}

In the 1979 study (Table 3), which was shortened because of drought induced lack of forage, weight gains show that steers supplemented with either barley or the CP supplement on the $45-\mathrm{N}$ pasture tended to gain more than unsupplemented steers, but differences were not significant. However, weight gains of steers that received either ba rley or the $C P$ supplement on the $0-N$ pasture were greater $(P<.05)$ than gains of unsupplemented steers. The efficiency of gain for the additional weight on the $0-\mathrm{N}$ pasture attributable to supplementation was 4.1 and $5.3 \mathrm{~kg}$ feed $/ \mathrm{kg}$ gain, respectively, for the barley and $C P$ supplemented steers.

Weight gain of steers grazing the $45-\mathrm{N}$ and $\mathrm{O}-\mathrm{N}$ pastures were plotted with diet CP and IVDOM in Figures 2 and 3, respectively.
Weight gain for the entire grazing season is shown for comparison with forage chemical composition, even though the supplementation study involved only the last part of the season.

Crude protein for the $45-\mathrm{N}$ pasture did not drop below the NRC requirement for $.9 \mathrm{~kg} /$ day gain until about the time this portion of the study was terminated, which explains why a significant response to CP supplementation was not obtained. Weight gain increased at a near linear rate while IVDOM declined from 66 to less than $52 \%$ by August 29 . Little change in IVDOM was measured during the remainder of the season.

The relationship between weight gain, diet CP, and IVDOM for the $0-\mathrm{N}$ pasture (Fig. 3) shows that a response to both $\mathrm{CP}$ and energy supplementation began about mid-August when $C P$ was just over $9 \%$ but rapidly declining. Weight gain increased at a near linear rate until October 4, while IVDOM quickly declined to near $52 \%$ by July 31 . Supplementation of either energy or CP appeared to be beneficial on both the 45-N and $0-\mathrm{N}$ pasture when IVDOM declined to about $52 \%$ but the response began much earlier in the season and resulted in a much greater difference on the $0-\mathrm{N}$ pasture. It cannot be determined from these data whether the beneficial effect of supplementation was caused by CP, energy, or by a combination of the two.

\section{Discussion}

In 1977, NDF was higher for the $0-\mathrm{N}$ pasture, and in 1978, it was higher for the 45-N pasture. Crude protein was higher and lignin lower for the 45-N pasture in all 3 years. In 1977 and 1979, IVDOM was higher and ADF lower $(P<.05)$ for the $45-N$ pasture. Differences between the $45-\mathrm{N}$ and $0-\mathrm{N}$ pastures in 1977 and 1979 were caused in part by the dilution effect of old plant growth in the $0-\mathrm{N}$ pasture.

Rainfall pattern during the growing season was found to be the

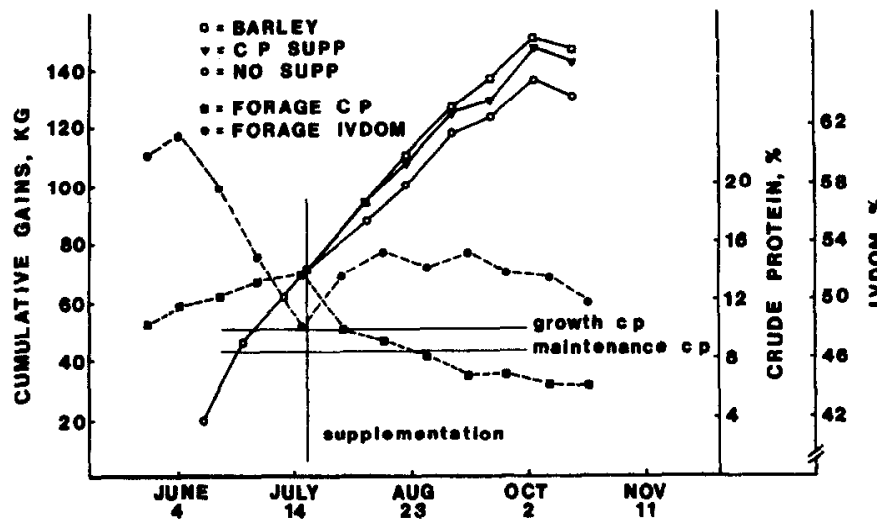

Fig. 3. Cumulative weight gains, forage $C P$ and IVDOM on the $0-\Lambda$ pasture, 1979.

Fig. 2. Cumulative weight gains, forage CP and IVDOM on the 45-N pasture, 1979.

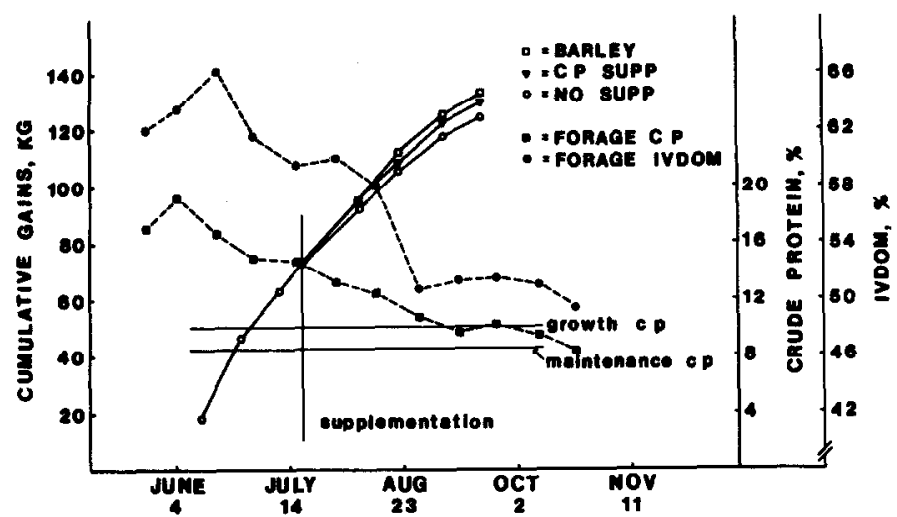


major factor influencing chemical composition of 6 native grasses of the High Plains of Texas (Willard and Schuster 1973). Erratic precipitation patterns are a major factor in determining whether a forage species remains actively growing vegetatively, goes into dormancy, or matures reproductively. Precipitation in the Northern Great Plains is also of ten erratic, as indicated by the precipitation data presented in Table 2.

There was a seasonal decline $(P<.05)$ in IVDOM all 3 years; however, in 1978, most of the decline had occurred by July; in the other 2 years the change was more gradual. Crude protein decreased and ADF increased $(P<.05)$ with advance in season in all 3 years. There was a seasonal increase $(P<.05)$ in NDF the first 2 years, but lignin only increased $(P<.05)$ during the season in 1978. Similar chemical composition changes in selected native grass species have been reported by Burzlaff (197l) and Cogswell and Kamstra (1976); however, all species did not change at the same ratc. McClung et al., 1976, also reported a seasonal decrease in CP in esophageal fistula diet samples taken from the Texas High Plains.

Steer gains in 1978 (Fig. 1) dropped dramatically when IVDOM declined to around $50-52 \%$. A similar response was not measured in 1979 suggesting that mid-summer steer gains may have been more closely related to environmental conditions than pasture quality.

The erratic results with CP supplementation indicate that steers were not consistantly selecting a diet deficient in CPduring the late summer-early fall period as might be expected. The data indicate that supplementation with barley would be beneficial more often than with a supplement higher in CP. However, either barley or a CP supplement must be used to complement dietary forage, and the data demonstrate that dietary forage quality does not necessarily follow a classic plant maturity curve. Year differences in animal response to supplementation are the result of differences in the quality of forage available to the grazing animal as influenced by precipitation amount and pattern.

When 1977 and 1978 ES steer gains were analyzed together (Table 3), no significant benefit was obtained from early summer supplementation. However, Denham (1977) did obtain increased gains over a 32-day spring supplementation period with $.45 \mathrm{~kg}$ concentrate. When the 1978 and 1979 LS data were analyzed together, a response $(P<.05)$ was obtained from either barley or $\mathrm{CP}$ supplementation for both the $45-\mathrm{N}$ and $0-\mathrm{N}$ pastures in late summer. A 30-day response to fall supplementation was also reported by Denham (1977), but as in our study it was not clear whether the response was due to $\mathrm{CP}$, energy, or both. When the two years data were combined, we show that 6.3 and $6.9 \mathrm{~kg}$ barley $/ \mathrm{kg}$ gain and 5.8 and $10.6 \mathrm{~kg} \mathrm{CP}$ supplement $/ \mathrm{kg}$ gain were required to produce the additional weight on the $45-\mathrm{N}$ and $0-\mathrm{N}$ pastures, respectively. The economics of barley supplementation is illustrated by the following example. If barley were priced at $13.3 \mathrm{c}$ per $\mathrm{kg}(\$ 2.90$ per bu), the daily cost of supplemental barley per steer would be $9 \mathrm{c}(13.3 \mathrm{c} \times .68 \mathrm{~kg}$ barley). Average daily weight gain per steer attributed to barley over the 2 years was .11 kg (Table 3). If yearling steers were selling for $\$ 1.32$ per $\mathrm{kg}(60 \mathrm{clb})$, the value of the gain would be $14.5 \mathrm{c}(\$ 1.32 / \mathrm{kg} \times .11 \mathrm{~kg})$, thus supplemental barley would have a net value of $5.5 c(14.5 c-9.0 c)$ per steer per day or $\$ 4.95$ per steer over a 90 -day grazing period. The market value of barley and steers will of course determine whether barley supplementation is a viable alternative to the producer.

\section{Literature Cited}

Burzlaff, D.F. 1971. Sea sonal variations of the in vitro dry-matter digestibility of three sandhill grasses. J. Range Manage. 24:60-63.

Cogswell, C., and L.D. Kamstra. 1976. The stage of maturity and its effect upon the chemical composition of four native range species. J. Range Manage. 29:460-463.

Denham, A.H. 1977. Influence of energy and protein supplements on grazing and feedlot performance of steers. J. Anim. Sci. 45:1-7.

Lorenz, R.J., and G.A. Rogler. 1972. Forage production and botanical composition of mixed prairie as influenced by nitrogen and phosphorus fertilization. Agron. J. 64:244-249.

McClung, J.E., R.C. Albin, and J.L. Schuster. 1976. Summer diets of steers on a deep hardland range site of the Texas High Plains. J. Range Manage. 29:387-389.

Moore, J.E., and G.O. Mott. 1974. Recovery of residual organic matter from in vitro digestion of forages. J. Dairy Sci. 57:1258-1259.

National Research Council. 1976. Nutrient requirement of domestic animals: No. 4. Nutrient requirements of beef cattle. Nat. Acad. Sci., Washington, D.C.

Obioha, F.C., D.C. Clanton, L.R. Rittenhouse, and C.L. Streeter. 1970. Sources of variation in chemical composition of forage ingested by esophageal fistula cattle. J. Range Manage. 23:133-136.

Raleigh, R.J. 1970. Sym posium on pasture methods for maximum production in beef cattle: Manipulation of both livestock and forage management to give optimum production. J. Anim. Sci. 30:108-114.

Rogler, G.A., and R.J. Lorenz. 1965. Nitrogen fertilization of natural grasslands in the Northern Plains of the United States. Proc. 9th Int. Grassland Congr. 1327-1330.

Tilley, J.M., and R.A. Terry. 1963. A two stage technique for the in vitro digestion of forage crops. J. British Grassland Soc. 18:104-111.

Van Soest, P.J., and R.H. Wine. 1967. Use of detergents in the analysis of fibrous feeds. IV. Determinations of plant cell-wall constituents. Assoc. Off. Anal. Chem. J. 50:50-55.

Van Soest, P.J., and R.H. Wine, 1968. Determination of lignin and cellulose in acid-detergent fiber with permanganate. Assoc. Off. Anal. Chem. J. 51:780-785.

Willard, E.E., and J.L. Schuster. 1973. Chemical composition of six Southern Great Plains grasses as related to season and precipitation. J. Range Manage. 26:37-38. 